\title{
Religious Toleration as a Subject for World Education? Past and Present Perspectivesfor Students the World Over Based on Literary-Historical Material
}

\author{
ALBRECHT CLASSEN \\ Department of German Studies, University of Arizona, Tucson, AZ 85721, USA.
}

\begin{abstract}
This study reexamines the meaning of education in global terms as the foundation of all open and democratic societies both in the past and the present. Literary studies create useful mirrors taking the learner into the past where parallel cases of human problems and conflicts existed. The learning experience then allows the individual to carry the new insights back to the own presence and to apply them to current situations. This process can and must be applied particularly to the principle of tolerance, one of the highest ideals in all of education. In order to illustrate this concept, this study examines Boccaccio's Decameron and Gotthold Ephraim Lessing's Nathan the Wise as model cases for global education leading to a more peaceful and mutually respectful world. With all due respect for religion, hating and murdering other people for religious reasons betrays the very principles of that religion whatever denomination or creed it might be. Ignorance and lack of education make it possible for fanatics or zelots to whip the masses into violent actions against those who adhere to another faith. One of the major tasks by educators is to introduce rationality, mutual respect, honor, and dignity, which is all possible through an intensive study of well-chosen literary texts for class discussions addressing world religions.
\end{abstract}

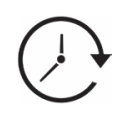

Article History

Received: 13 November 2020

Accepted: 19 May 2021

\author{
Keywords \\ Boccaccio; \\ Lessing; \\ Toleration; \\ Tolerance; \\ universal Education.
}

\section{Introduction}

At the risk of carrying coal to Newcastle, this study will examine once again the meaning of education on a global level in order to set the stage for a critical examination of the topic 'tolerance' to be taught and discussed via literary examples from the past in every classroom in East and West, North and South. Tolerance appears to be more and more endangered today, with ever more countries and societies moving away from their traditionally open

CONTACT Albrecht Classen $\$ aclassen@email.arizona.edu 9 Department of German Studies, University of Arizona, Tucson, AZ 85721, USA.

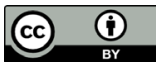

(c) 2021 The Author(s). Published by Enviro Research Publishers.

This is an $\partial$ Open Access article licensed under a Creative Commons license: Attribution 4.0 International (CC-BY).

Doi: http://dx.doi.org/10.12944/CRJSSH.4.1.03 
approach and the democratic principles. Autocratic regimes are gaining increasingly influence and power, which raises the critical question of how we as educators can and should get involved in contributing to the improvement of this world. It is a fundamental premise of this investigation that democracy, or a similar political system, and a stable social network helping all people within a society when they are in needrepresents a highly positive value, whereas societies determined by a leader or party cult, demanding complete support of the government without any freedom to voice one's own opinion would have to be identified as backwards, repressive, and under-developed in light of hundreds of years of critical theory, enlightenment ideals, and humanitarian values as the essential fundamentals in our modern existence. More troubling today also seems to be the growing willingness of large sections of human society in many countries of this world to subscribe to intolerance, violence, aggression, and hostility, targeting any minority group available to unleash personal frustration, Angst, and an inferiority complex. Even at the risk of being overly optimistic, this article will outline strategies of how to employ literary texts from the past that promise to help us in combatting these dangerous tendencies and in pursuing strategies to build our future, more tolerant society. Educators have, in fact, a major role to play in the improvement of our world, maybe today even more than ever before, especially in light of rising racism and intolerance, and hence of violence at every level of society. It might be idealistic to believe that the study of literary texts might have the desired effect, but the intensive engagement with the issues outlined in them creates a discourse which will actively involve all participants in a school class or a university seminar. And, as I suggest here, sometimes even very old texts have an enormous potential to achieve the desired results of educating, transforming, and enlightening the young generation for the future.

\section{Once Again: Educating the World}

Education might well be one of the noblest professions in the world, whether in Kindergarten or at the college level, at least for those who have the right ideals, the true stamina, and the technical skills necessary for this job. An educator pursues per definitionem the goal of instilling knowledge and understanding in the child/pupil/student so that the individual can develop on his/her own and transform from an ignoramus into a fully-developed human being, capable of picking up the baton and enter into a process of self-learning and evolution.

True education is of a revolutionary kind because it empowers students to structure, guide, and shape their own world (Hooks, 1994; as to the history of the American education system, see Jeynes, 2007; cf. also Coté, 2007). Of course, there are many ways of learning on one's own, and many people have amazing natural talents in that regard. Nevertheless, throughout time, systematic education has always served a critical task to attain and maintain a certain level of knowledge and also wisdom in the young generation because without it the future will be at risk for all. Parents and teachers have always been called upon to collaborate in this endeavor, though the degree to which the learner profits from both respectively has regularly been a matter of debate and negotiations (home schooling versus public or private education). However, the most common denomination in all pedagogical discourses has always been shared universally, that is, the notion that education is of central importance for society at large.

The modesand conceptsof education differ vastly from country to country, from society to society, of course, whereas the fundamental ideal of education itself is not contested, irrespective of the social, political, or economic system. It can be carried out in pragmatic, hands-on terms, it can be done via a tutor/mentor, within a classroom setting, and it is currently, in light of COVID-19, primarily done digitally, online. Whatever the framework might be, we would certainly agree that the individual human being requires education. Even the most dictatorial systems accept the idea that education produces people who can operate successfully and allow society to function effectively. In those cases, however, education often is forced to observe strict ideological criteria and to repress free thinking by means of intellectual manipulation or propaganda. Aside from those extreme cases, however, in most countries of this world every possible level of education is appreciated and deemed essential (Nussbaum, 2010; Whittington, 2018; Dhingra, 2020).

As much as we as people need to learn the basics of speech, mathematics, geography, reading 
and writing, biology or chemistry, as much do we require solid understanding of our ethics as human beings; an issue which has become increasingly contested and problematic in the current day and age. Critics, however, might ask why an individual would still need to know anything about history, the arts, music, medicine, or geometry if it all can be found online, such as in Wikipedia? The answer is rather self-evident, since all our well-established knowledge derives from the past and only partially prepares us for the future, as our ongoing research in all fields of human endeavors confirms. In short, education needs to strive toward several goals at the same time, helping the learner to acquire the basic understanding of the well-established canon, and to gain the intellectual capacity to think about those data and move beyond them, if necessary or possible.

We are forced today to cope with enormous challenges in ethical and moral terms, and only wellinformed individuals can make convincing, rational, sympathetic decisions as to how we as people want to or can operate meaningfully and responsibly in a world increasingly controlled by computers or robots (Steinkellner, 2012; Münster, 2020). A society in which young people turn into automatons and killing machines who carry out assassination attacks against innocent victims upon a religious or political leader's commands or instigation - see the murder cases in France, Germany, and Austria in the fall of 2020 , see the military situation with ISIS in Iraq since 2011, or see the bombing in Oklahoma City in 1995 - has already begun to crumble under its own weight and has fundamentally failed in its educational requirements and ideals. In such a society, the basic human principles of freedom, justice for all, and tolerance have not reached all members, or are explicitly rejected out of racist, religious, and political reasons. Without tolerance, however, an ever-growing number of people within a society will suffer from subjugation, marginalization, repression, if not elimination (genocide).

Of course, all this does not tell us clearly and specifically what education is supposed to be, and the possible answers would easily reveal their own political bend. We can be certain, however, that a free democratic country has always relied on the Humanities as its corner stone because it is there where the critical understanding and awareness about basic human behavior and values are developed, drawing from a vast treasure trove of literature, historical documents, visual objects, musical compositions, philosophical treatises, and religious writings (Smith, 2011; see now the contributions to Classen, ed., 2020). This is not to say that a good school system would be a guarantee for a good political government, or a peaceful, functioning open society, as the ongoing criminality everywhere underscores most dramatically. However, a society without a good education system is in danger of moving to the brink of extinction, at least as a free and democratic society, giving way to a military dictatorship or a theocracy.

\section{Wilhelm von Humboldt}

The famous Prussianminister and philosopher, Wilhelm Humboldt (1767-1835), once formulated the following in a letter to the Prussian King Frederick William III:

There are undeniably certain kinds of knowledge that must be of a general nature and, more importantly, a certain cultivation of the mind and character that nobody can afford to be without. People obviously cannot be good craftworkers, merchants, soldiers or businessmen unless, regardless of their occupation, they are good, upstanding and - according to their condition - well-informed human beings and citizens. If this basis is laid through schooling, vocational skills are easily acquired later on, and a person is always free to move from one occupation to another, as so often happens in life. (Günther, p. 132; cf. Humboldt).

Moreover, as he formulated elsewhere, succinctly summarizing his basic educational philosophy:

The aim is harmonious development of all mental faculties through languages and literature, mathematics and the natural sciences. Schoolleavers preparing to enter university should have the following qualifications: all-round formal intellectual training, a sound knowledge of the languages of scholarship, a solid understanding of, and considerable skill inthe mathematical sciences and, lastly, a thorough grounding in the natural sciences and history. Such students can choose any course of studies they like and feel equally at home, as they will always possess the requisite intellectual tools. In no field - philology, theology, law, mathematics, natural sciences or medicine - will they be assigned 
tasks for which they are unprepared. (Günther, p. 133; cf. Benner, 2003).

Those ideals continue to reverberate throughout the western world and also prove to be the fertile ground for the discussion of tolerance. Subsequently, however, the intention of this paper is not to pursue the history of western education at large, whether in Germany or the United States, the latter closely founded on the Humboldtian principles (Backhaus, 2015; Tenorth, 2018), as fascinating and insightful as this would promise to be in light of the many discussion as to how to reform our schools today to meet the new demands of our future (Hermann, 2017). The question here focuses on the issue of tolerance and how it could and should be taught globally, a topic which is of pressing need today in the $21^{\text {st }}$ century perhaps more than ever before, especially in light of the growing ideological and religious tensions in many parts of our world.

\section{Teaching Toleration and Tolerance}

Tolerance constitutes a highly advanced ideal which philosophers and writers have discussed already for many centuries, even as early as in the Middle Ages (Classen, 2018). There are specific differences between tolerance and toleration, which highlight the critical need for our world today to invest much more energy and resources into our school systems because without either one or the other being firmly subscribed to by the young generation, the growth of violence on a personal and a public level will only continue. Toleration assumes a hierarchical system, with the majority (religion, race, gender, age, etc.) accepting the minority as part of the whole, but only conditionally, not conceding at all that the other religious or racial group might be entitled to the same social and economic privileges, the same space, the same respect, or the same public relationship, for instance. From the Middle Ages to the present time, Christian countries have tolerated, but not really accepted their Jewish neighbors, and whenever any kind of problem emerged affecting society at large, Jews were immediately targeted and scapegoated again (Eriksen, Harket, and Lorenz, 2005/2019). The Holocaust was not a completely new approach pursued by the Nazis; it differed from previous pogroms and expulsions only in degree and in the systematic, mechanistic, and totalitarian approach pursued by the state under Hitler's brutal leadership.
Tolerance, however, represents an ethical and moral ideal on a very different level. It means that the representatives of one faith, one ideology, or one school of thinking accepts a representative of another group on an equal level and acknowledges that both sides might be right. The truly tolerant person does not insist that his/her position or faith constitutes the only 'true' one and entertains the notion that it might be wrong. This does not mean that tolerance would lead to a world of relativity and lack of values; instead, it recognizes that society is made up of many different people who might disagree with each other in matters of religion or political convictions but who certainly agree that everyone has the same right to voice that opinion and to defend it even publicly, as long as the rules of engagement pertain to all parties involved, basically following the universal Golden Rulewhich has been formulated in practically all major cultures and religions (https://en.wikipedia. org/wiki/Golden_Rule).

A fundamentally relevant concept behind tolerance states that there is no absolute truth in faith, truth as being the result of verification and falsification, something which scientists might be able to achieve, whereas already historians face serious challenges in determining 'the truth' about past events or individuals. In the case of tolerance, personal assumptions and beliefs are validated by all sides, without the need that anyone would have to give up his/her own position. Faith is one thing, material and political reality is another; both sustaining each other, but not conditionally.

To illustrate this aspect within a Christian context, let us consider the curious phenomenon of mysticism, best represented by such medieval and early modern individuals as Hildegard of Bingen, Elisabeth of Schönau, Mechthild of Magdeburg, Bridget of Sweden, Catherine of Siena, Julian Norwich, Margery Kempe, Heinrich Seuse, Johannes Tauler, or Theresa of Avila (Dinzelbacher, ed., 1989; McGinn, 1998; Dinzelbacher, 2012). Most of these mystics were accepted by the official (Catholic) Church as God's own mouthpieces, others, however, such as Marguerite de Porète or Joan of Arc were rejected and then burned at the stake for their alleged heresy. 
Today, we can only marvel at the astounding poetic power expressed by those writers who put down in writing their visions and revelations. Does our admiration transform those accounts into truth documents? Not at all, and until today there are many individuals, scholars and lay people, who simply question the foundation of all mysticism and identify it as the outcome of psychological fantasies. But who are we to qualify such ineffable phenomena? No one forces us, of course, to embrace mysticism for ourselves, but why would we require that modern-day rational people ought to dismiss mysticism altogether. Those who subscribe only to toleration would grant mystics their own existence, but possibly belittle or marginalize them. Those who pursue tolerance, on the other hand, would grant that mystical visions appear to be highly private and powerful spiritual experiences that might have been the result of concrete encounters between the human soul and the Godhead, or the result of imagination and fantasy (Classen, 2015; Classen, 2020a, pp.92-97).

In light of the timeless struggles and conflicts among the world religions, we need to return to the old question of how we can teach tolerance on a global scale. And we also need to ask the truly simple, yet tough question, why we should teach it. There are many countries still today where one specific religion or political ideology determines all of public life, and any deviation by individuals is then perceived as a threat to society at large, not to speak of the higher being worshipped there. In the name of religion, countless crimes have been committed, wars have been fought, and hatred has been stoked. But no divine being has ever descended from heaven to confirm its approval of those horrible acts of violence.

It might be overly optimistic and idealistic to assume that a proper, in-depth, humanisteducation system as envisioned by Wilhelm von Humboldt and many others could prevent terrorism, aggression, and/ or crime. But without those ideals, society would no longer move forward and become instead the victim of extremists who do not care about other members of society and only listen to radical voices that promise glory and respect, honor and dignity as the result of a person's mass killing. Education all by itself promises to yield much higher results in young people's minds than the police force, legal courts, the prison system, and the entire weight of the government, democratically elected or not.

\section{Literature as a Pivotal Medium to Teach}

Drawing from literary examples created in the past allows any teacher/instructor/professor to turn the students' attention away from the doldrums of daily politics and ideological strife toward ideals and values as presented in a fictional framework, that is, almost like on a petri dish placed underneath a microscope. Teaching literature thus emerges as a most critical strategy to illustrate to the young generation how to see their own world in theoretical and then also pragmatic terms. A poem, a novel, a romance, or a play serve, seen through this lens, as a significant theoretical platform for the reader/ listener where ideas are presented and acted out on a fictional stage, although this certainly mirrors reality in its own terms. Thus, the literary work transforms into a learning lab where human life by itself is experimented with, and where we as the audience are invited to reflect upon the myriad of options individuals have available to them to carry out their own lives and to transform their ideals into reality.

Moreover, the literary text tends to represent extreme cases which profile the issues at stake more clearly than even in practical terms. In education, hence, a fictional platform can enable intensive discussions that might be more objective than those involving real people and real situations. In fact, the further we go back in selecting relevant texts for the exploration of social, political, ethical, moral, or religious issues, the more we face a level of stability for the learning process which contemporary works can hardly offer (Grobman and Ramsey, 2020, pp. 51-60; for parallel perspectives in the field of history, see Demandt, 2020). After all, in order to exist and to thrive, we must make sense of this world, which demands much more than only scientific or medical knowledge (Drakeman, 2016; Madsbjerg, 2017).

Although most scholars would assume that the discourse on toleration and tolerance did not set in until the age of the Enlightenment, as promoted by individuals such as Voltaire and John Locke, we have been able to identify its roots already in the early and high Middle Ages (Nederman, 2000; Schmidinger, ed., 2002; Classen, 2018). We are still very far away from realizing the ideal of tolerance 
for ourselves, whether in the West or in the East, although it has been enshrined already into many western constitutions and fundamental laws. The struggle to transform people into tolerant thinkers and individuals who actually practice this ideal by themselves without any coercion will continue, and there is no guarantee for progress. The danger of falling behind and of becoming trapped by barbarism is always present, which makes education at every level so important. After all, ethics and morality are not engrained in the human DNA, and every new generation has to learn the basic ideals and values that hold us together once again as a free society. Otherwise, the horrible assassinations or mass killings in various European and other countries in the Fall of 2020 would not have been possible - see also the global conflict between the Shiites and Sunnis, with huge numbers of casualties in Afghanistan, Iraq, in the the war between Yemen and Saudi-Arabia, etc. The liability that individuals become indoctrinated and misled by their 'leaders' or spiritual guides is very high, today maybe even more than ever before because of the endless possibilities by the social media and computer networks (O'Grady, 2019).

\section{Boccaccio's Decameron: A Platform forTolerance}

There are almost countless possibilities available today to establish a reading list focused on historicalliterary and religious-philosophical treatments of toleration (and tolerance), and this already in the Middle Ages and the early modern age (Classen, 2020b). Many individuals pursued the ideal more or less in private, whereas others propagated it energetically in public through their poems or narratives. Two truly famous examples can be found in Giovanni Boccaccio's Decameron, a collection of tales in prose published around 1350. The entire work is predicated on the idea that a group of seven ladies and three gentlemen meet in Florence during the height of the Black Death and decide to leave the city for health reasons. While they spend their time on their various estates, they decide to tell each other stories, one person each every day, and this for ten days, which makes up a total of 100 stories, hence the title of the collection (Boccaccio).

Most of these stories reflect on erotic affairs, adultery, deception, foolish behavior, tragedy, misfortune, war, and the like. There are also at times accounts about the interactions between the representatives of the three world religions, Islam, Judaism, and Christianity. In the ninth story of the tenth day, for instance, the Italian merchant Torello strikes a friendship with three noble foreigners, whom he identifies as wealthy and highly worthy merchants or aristocrats. He tries everything in his power to demonstrate utmost hospitality, but he never learns their true identity, which is of no real concern for him. The more he showers gifts upon them, the more his own nobility is increased. Those foreigners are really the Muslim Sultan Saladin and his companions who try to spy among the Christians because they are preparing for a new crusade. Afterwards, Torellojoins the army and travels to the Holy Land where they are badly beaten by Saladin and taken prisoners or rather slaves. Torello, at that point unrecognized by the Sultan and assigned to him as chattel, serves as his falcon master, and gains Saladin's great respect. One day, however, the latter recognizes Torello's identity, immediately sets him free, and treats him as his best friend.

The story follows more twists and turns, particularly involving Torello's wife left behind and her being pressured by her relatives to marry again, but for our purposes suffices it to realize that Boccaccio here projected an ideal case of truly noble individuals who respect each other because of their refined character and who hence treat each other with great honor. There is never any question about each other's religion, and at the end Torello is transported overnight back to his home country, just in time to prevent his wife from marrying another man. Although situated within a Christian context, the narrator presents the Islamic world and also the sphere of magic as completely equal to Christianity, as long as the protagonists demonstrate a noble character, as is the case with Saladin and Torello.

Much more important proves to be the third story told on the first day where the Jew Melchizedek is put under pressure by the Sultan to lend him a large amount of money, which he normally would not do. However, Saladin poses the deceptive question to him "whether the Jewish, the Saracen, or the Christian" law he would deem to be the right and authentic one (p. 42-43). Melchizedek realizes quickly that there would not be any reliable and safe strategy for him to respond without incurring the Sultan's wrath, so he resorts to a short story within the story. He tells him the account of a rich, wealthy 
man who owns a most precious ring. Determined to make this to a perpetual heirloom, he designates this ring as the key token for the one son who would inherit it to become the fully-authorized heir of all of the family estates.

This method works well, and this actually for many generations to come, until one day there is a father who has three excellent sons whom he loves equally. Not being able to decide whom to entrust the one and only ring, he has secretly two copies made, so he can give one ring to each one of his sons as a sign of his love and respect for them all. The father then dies, which opens a bitter contest among the sons who all would like to emerge as the one and only heir to the family estate. The outcome is a negative and a positive one because the true ring cannot be determined, so the fight over who was the father's most beloved son is then not answered.

Melchizedek then turns to the Sultan and offers his explanation, which has resonated throughout the centuries and ought to be considered as a central source for discussions in classrooms all over the world:

And I say to you, my lord, that the same applied to the three laws which God the Father granted to His three peoples, and which formed the subject of your inquiry. Each of them considers itself the legitimate heir to His estate, each believes it possesses His one true law and observes His commandment. But as with the ring, the question as to which of them is right remains in abeyance.

$$
\text { (p. 44). }
$$

Boccaccio thus argues that religion is of a highly private nature and cannot be decided on by means of logic, rules, laws, or physical power. With this simple parable, the poet has created a universal platform for the clear illustration why religion should not divide people and why tolerance should be of paramount importance in every society of this world.

\section{Gotthold Ephraim Lessing: A Spokesperson for Tolerance Well Before out Time}

This motif exerted a long-term influence and reemerged especially in the famous play by the German playwright Gotthold Ephraim Lessing, Nathan the Wise (1779). It would go too far here to discuss the entire text once again, which proves to be complex and philosophically profound, as many scholars have determined already over many decades by now (see Nisbet, 2013, for instance). But the Jew, here called Nathan, characterized with the epithet 'the Wise one,' confronts the same challenge by the Sultan Saladin who would like to extort money from him in order to maintain his government and military. Nathan realizes, just as in Boccaccio's version, the secret plan behind the question regarding the 'true religion,' and he deflects by telling a story once again.

Nathan understands immediately that this demand to reveal the truth about religion can only be a deceptive strategy, so he also turns to this ancient account and basically repeats what we have already learned from Boccaccio's story. Then, however, Nathan adds a significant twist insofar as the three sons, all holding the 'authentic' ring, demand from a judge to decide the case. However, the goldsmith had created such masterpieces that no one can distinguish any of those rings. The judge then turns it all around and finds a Solomonic solution:

But hold-you tell me that the real ring Enjoys the hidden power to make the wearer Of God and man beloved; let that decide. Which of you do two brothers love the best? You're silent. Do these love-exciting rings Act inward only, not without? Does each Love but himself? Ye're all deceived deceivers, None of your rings is true. The real ring Perhaps is gone. To hide or to supply Its loss, your father ordered three for one.

Following this train of thought, the judge then continues and concludes most insightfully:

This is my counsel to you, to take up The matter where it stands. If each of you Has had a ring presented by his father, Let each believe his own the real ring. 'Tis possible the father chose no longer To tolerate the one ring's tyranny; And certainly, as he much loved you all, And loved you all alike, it could not please him By favouring one to be of two the oppressor. Let each feel honoured by this free affection. Unwarped of prejudice; let each endeavour To vie with both his brothers in displaying The virtue of his ring; assist its might With gentleness, benevolence, forbearance, With inward resignation to the godhead, And if the virtues of the ring continue To show themselves 
among your children's children, After a thousand thousand years, appear Before this judgmentseat-a greater one Than I shall sit upon it, and decide. So spake the modest judge.

(Act III; here borrowed from the English translation by William Taylor, 1893; https://www.gutenberg. org/files/3820/3820-h/3820-h.htm; for the critical edition, see Bohnsen and Schilson, eds., 1993)

The differences between the religions are those determined by demonstrations of love, and only that religion which would appeal to most people on a voluntary basis could then claim to be closest to truth. Significantly, however, this little parable is couched in a much larger literary framework because the entire play is predicated on practicing tolerance. As we learn at the end, the protagonist Nathan had lost his entire family a long time ago when a murderous gang of Christians had burned down his house. Yet, he then adopted a Christian orphan girl and raised her like his own daughter. When the play sets in, we encounter a young Knight Templar who had been taken captive by the Sultan's soldiers but who was then suddenly spared his life because Saladin had recognized in his facial features those of his long-dead brother.

This young man then saved Nathan's daughter from a fire, although he hates Jews, not knowing who this pretty woman was. In the course of time, the Templar realizes that Nathan possesses the kind of character which he greatly esteems, and he then falls in love with his daughter. As it turns out at the end, there are many different family bonds. Nathan at first opposes the possible marriage between his daughter and the Templar, specifically because he has a hunch which then proves to be correct. The Templar was the son of a German noble lady and her husband, Saladin's brother. And Nathan's adopted daughter then turns out to be his sister. The Sultan is deeply moved and embraces the two young people, and extends his friendship to the Jew.

Altogether, then, this old and wise Jew brings together the entire family, bridging the three world religions and practicing himself the ultimate ideal of tolerance. His own profound suffering led him to the realization that violence or counter-aggression cannot be the answer; instead, he embraced the ideals of love, which he fully extended to his adopted daughter raising her to the best of his abilities without forcing any religious concepts upon her. During the time when we see him on the stage, he can convince the Templar that Jews can be honorable and dignified individuals; and the Sultan is easily swayed to pay great respect to Nathan, while they all have to realize that Saladin is a truly humanist in his heart and thus their friend. In a way, then, the Jew did not only tell a parable in the vein of Boccaccio's model, but expanded it considerably with a further religious dimension supported by a strong sense of tolerance. Ultimately, Nathan represents the ideal character impersonating the value of tolerance, which he embraces with his full heart, without abandoning his own Jewish culture and background.

Many other voices could be brought to the table in order to exemplify the concept of tolerance as mirrored in a literary text, whether we think of Wolfram von Eschenbach or Rudolf von Ems, of Ramon Llull or Marco Polo, Don Juan Manuel or Bartolomé de Las Casa. In fact, the sixteenth century witnessed ever new commentators who argued for religious freedom, for the freedom of the indigenous population of the New World, and for freedom on a private level in the urban settings of early modern Europe (Classen, 2020b).

\section{Pedagogical Applications and Conclusion}

The literary examples could be easily dismissed by anyone who is deeply determined by fundamental thinking and driven to demonstrate to the world that his/her own religion justifies any kinds of atrocities in order to overcome the so-called infidels. If murder becomes justified in a person's mind, then there are not many bridges left to engage with him/her in any constructive fashion. After all, all dialogue and all forms of communication that aim at achieving a workable outcome must rely on a combination of give and take, and a certain degree of individual humbleness. For most of our students, however, these literary examples from the fourteenth and eighteenth centuries offer powerful catalysts to embark on deeper reflections as to the meaning of a 'true' religion, on the relationship between subjective and objective perspectives and perceptions, and on the need for all functioning societies to observe compromise, coordination, communication, compassion, and a sense of community. 
The critical analysis of both literary texts, among many others, creates a solid platform for discussions about the fundamental nature of toleration and tolerance, irrespective of the cultural framework or pedagogical settings. The historical character of these texts moves them further away from the modern reader, which is not of a disadvantage, but a great advantage because it facilitates an easier discussion without the need to confront the own reality so drastically heads-on, though that still will have to be addressed subsequently, but then by means of a new understanding of tolerance as illustrated by those literary texts. Of course, our brutal reality is never going away, and it is that reality which education must also address. However, the literary analysis makes possible the critical reflection of the theoretical concepts, which then can be translated and adapted to all kinds of other cultural and social conditions.

Both the Italian and the German text carry tremendous and far-reaching meaning for all people here on earth, and this also today. Religion is not dismissed at all, neither by Boccaccio nor by Lessing, but it is identified as a belief system adopted by an individual mostly because of one's cultural conditioning. True religion as an institution does not exist, but the person who knows how to display love for humankind emerges as the true representative of a religious mind. Educators around the world here face highly potential opportunities to engage with their students about truly fundamental issues. Confronting them with the messages by Boccaccio and Lessing, for instance, facilitates a powerful learning experience in a cross-cultural and timeless fashion and thus also a transformation of the human mind, moving it away from hatred to love, and this not at all in opposition to religion, on the contrary.

\section{Acknowledgment}

This is my latest research paper based on extensive examinations for two books on the history of toleration and tolerance in the Middle Ages and the Early Modern Age (2018 and 2020). The present paper offers specific applications for international education.

\section{Funding}

No funding sources.

\section{Conflict of Interest}

There is no conflict of interest.

\section{References}

1. Backhaus, Jürgen G. 2015. The University According to Humboldt: History, Policy, and Future Possibilities. Cham: Springer.

2. Benner, Dietrich. 2003. Wilhelm von Humboldts Bildungstheorie. Weinheim: Juventa.

3. Boccaccio, Giovanni. 1972/1995. Decameron, trans. with an intro. and notes by G. H. McWilliam. Sec. ed. London: Penguin.

4. Bohnen, Klaus, and Arno Schilson, ed. 1993. Gotthold Ephraim Lessing, Werke 1778-1780. Werke und Briefe, 9. Frankfurt a. M.: DeutscherKlassiker Verlag.

5. Classen, Albrecht. 2020a."Imagination, Fantasy, Otherness, and Monstrosity in the Middle Ages and the Early Modern Age," Imagination and Fantasyin the Middle Ages and Early Modern Times: Projections, Dreams, Monsters, and Illusions, ed. Albrecht Classen. Fundamentals of Medieval and Early Modern Culture, 24 (Berlin and Boston:
Walter de Gruyter, 2020), 1-229.

6. Classen, Albrecht. 2020b. Religious Toleration in the Middle Ages and Early Modern Age: An Anthology of Literary, Theological, and Philosophical Texts. Berlin: Peter Lang.

7. Classen, Albrecht, ed. 2020. The Relevance of The Humanities in the Twenty-First Century: Past and Present. Humanities: https://www.mdpi.com/journal/humanities/ special_issues/pas_pre.

8. Classen, Albrecht. 2018. Toleration and Tolerance in Medieval and Early Modern European Literature. Routledge Studies in Medieval Literature and Culture, 8 (New York and London: Routledge.

9. Classen, Albrecht. 2015. "Toleration and Tolerance in the Middle Ages: Medieval Perspectives for Our Future," The Living Pulpit 24: 9-14.

10. Coté, Mark. 2007. Utopian Pedagogy: Radical Experiments Against Neoliberal 
Globalization. Toronto: Toronto University Press.

11. Demandt, Alexander. 2020. Magistra Vitae: Essays zum Lehrgehalt der Geschichte. Historica Minora, 4. Vienna, Cologne, and Weimar: Böhlau.

12. Dhingra, Pawan. 2020. Hyper Education: Why Good Schools, Good Grades, and Good Behavior Are Not Enough. New York: New York University Press.

13. Dinzelbacher, Peter. 2012. Deutsche und niederländische Mystik des Mittelalters: ein Studienbuch. Berlin and Boston: Walter de Gruyter.

14. Dinzelbacher, Peter, ed. 1989. Wörterbuch der Mystik. Stuttgart: Alfred Kröner.

15. Drakeman, Donald. 2016. Why We Need the Humanities: Life Science, Law and the Common Good. New York: Palgrave Macmillan.

16. Eriksen, Trond Berg, Håkon Harket, and Einhart Lorenz. 2019 (orig. 2005). Judenhass: Die Geschichte des Antisemitismus von der Antike bis zur Gegenwart. Aus dem Norwegischen von Daniela Stilzebach. Göttingen: Vandenhoeck \& Ruprecht.

17. Günther, K. 1988. "Profiles of Educators: Wilhelm von Humboldt (1767-1835). Prospects 18, 127-136. https://doi. org/10.1007/BF02192965.

18. Herrmann, Ulrich. 2017. Wilhelm von Humboldt: die 'Schulpläne' - neu gelesen: aus Anlass des 250. Geburtstags von Wilhelm von Humboldt am 22. Juni 2017." Zeitschrift für Religions- und Geistesgeschichte 69.2: 150-67.

19. Hook, Bell. 1994. Teaching to Transgress: Education as the Practice of Freedom. New York: Routledge.

20. Humboldt, Wilhelm von. 1964. Bildung des Menschen in Schule und Universität. Grundlagen und Grundfragen der Erziehung, 4. Heidelberg: Quelle \& Meyer.

21. Jeynes, William. 2007. American Educational History: School, Society, and the Common Good. Thousand Oaks, CA: SAGE
Publications.

22. Madsbjerg, Christian. 2017. Sensemaking: The Power of the Humanities in the Age of the Algorithm. New York: Hachette Books.

23. McGinn, Bernard. 1998The Flowering of Mysticism: Men and Women in the New Mysticism (1200-1350). New York: Crossroad.

24. Münster, Reinhold. 2020. "The Anthropocene, Technology and Fictional Literature." Humanities 2020. 9(3), 56; https://doi. org/10.3390/h9030056 - 02 Jul 2020.

25. Nederman, Cary J. 2000. Worlds of Difference: European Discourses of Toleration, c. 1100-c. 1550. University Park, PA: The Pennsylvania State University Press.

26. Nisbet, Hugh Barr. 2013. Gotthold Ephraim Lessing: His Life, Works, and Thought. Oxford: Oxford University Press.

27. Nussbaum, Martha C. 2010. Not for Profit: Why Democracy Needs the Humanities. Princeton, NJ: Princeton University Press.

28. O'Grady, Selina. 2019. In the Name of God: A History of Christian and Muslim Intolerance. London: Atlantic Books.

29. Schmidinger, Heinrich, ed. 2002. Wege zur Toleranz: Geschichte einer europäischen Idee in Quellen. Darmstadt: WissenschaftlicheBuchgesellschaft.

30. Smith, Martha Nell. 2011. „The Humanities Are Not a Luxury: A Manifesto for the TwentyFirst Century." Liberal Education 97.1: pp. 48-55.

31. Steinkellner, Clara. 2012. Menschenbildung in einer globalisierten Welt: Perspektiveneiner zivilgesellschaftlichen Selbstverwaltung unserer Bildungsräume. Berlin: Ed. Immanente.

32. Tenorth, Heinz-Elmar. 2018. Wilhelm von Humboldt: Bildungspolitik und Universitätsreform. Paderborn: Verlag Ferdinand Schöningh.

33. Whittington, Keith E. 2018. Speak Freely: Why Universities Must Defend Free Speech. Princeton, NJ, and; Oxford: Princeton University Press. 